\title{
PROVOKING MUSEOLOGY: THE GEMINAL THINKING OF ZBYNĚK Z. STRÁNSKÝ1
}

\section{BRUNO BRULON SOARES}

\section{ABSTRACT/ABSTRAKT:}

The paper intends to make a conceptual revision of the work produced by the Czech museologist Zbyněk Zbyslav Stránský (1926-2016), referring to the period between 1965 to 1995, when he was responsible for the attempt to conceive a theory for museology. With his metatheory, this thinker aimed to defend and sustain this discipline's scientific status. In his works, by refuting the museum as the study subject for this supposed "science", Stránský would discuss which should be its fundamental subjects of interest in its place, creating specific concepts for museology. With the terms musealia, museality and musealization he shifts the discipline's focus from the museum, as an instrument for a certain end, to the processes of attributing value to things. His theory generates, thus, the necessary foundation for the museological field, integrating theory and practice, and initiating a social and scientific reflection for museology. Therefore, the paper historicizes the process of configuration of disciplinary museology in Eastern Europe in order to understand what was in the base of the geminal thinking structuring this branch of knowledge and, at the same time, appointing new pathways for its future.

1 In memoriam Zbyněk Zbyslav Stránský.
Formování muzeologie jako vědy a myšlenkový odkaz Zbyňka Z. Stránského

Cílem tohoto př́spěvku je konceptuální přehled aktivit českého muzeologa Zbyňka Zbyslava Stránského (1926-2016), které se vztahují k období mezi lety 1965 až 1995, kdy se pokoušel vytvořit teorii muzeologie. Prostřednictvím této metateorie se Z. Z. Stránský snažil obhájit a posílit pozici muzeologie jako vědního oboru. Ve svých pracích Stránský vysvětloval, že předmětem studia této formující se vědy není muzeum samotné, ale že jsou jím jiné základní oblasti zájmu, čímž vytvářel specifické koncepce muzeologie. Prostřednictvím pojmů muzeálie, muzealita a muzealizace přesouvá ohnisko vědeckého zájmu muzeologie z muzea jako nástroje pro určitý účel $\mathrm{k}$ procesům přisuzování hodnoty předmětům. Jeho teorie tak vytváří potřebný základ pro obor muzeologie, který v sobě spojuje teoretické i praktické aspekty a vyvolává společenskou i vědeckou reflexi. Příspěvek proto pojednává o historii procesu etablování muzeologie jako vědy ve východní Evropě, který umožňuje lépe pochopit dvě základní roviny myšlení, jež pomáhaly formovat tento obor, a zároveň vytyčuje i nové cíle do budoucna.

\section{KEYWORDS/KLÍČOVÁ SLOVA:}

museology - Stránský - Brno school-musealization muzeologie - Stránský - brněnská muzeologická škola - muzealizace
"If thirty or even twenty years ago anyone had talked or written about museology as a science, many people would have reacted with a compassionate or a contemptuous smile.

Today this is, of course, different."

(J. G. Graesse, Zeitschrift für Museologie und Antiquitätenkunde, 1883)

"It is my opinion that knowledge of one's own history is a very important argument for every branch of science, when defending its existence."

(Zbyněk Z. Stránský, Museological News, 1985, no. 8)

At first, there were material objects. Then, there were museums occupying the center of the branch that gathered specific knowledge and practices, which has been called "museology". Among a few other pioneer thinkers, and maybe the most prominent of them all, Zbyněk Zbyslav Stránský (19262016) was responsible for the first contemporary attempt to give some conceptual structure to this new born discipline in the second half of the $20^{\text {th }}$ century. In the present paper we intend to revise some of his geminal ideas that are, still today, in the bases of museological thinking and that evolved in his works notably from 1965 to 1995.

In chemistry, the term geminal refers to a relationship that is established between two atoms or functional groups that are attached 
to the same common atom. The concept is important because functional groups attached to the same atom tend to behave differently from when they are separated. This movement of conversion, that is often observed in atoms, can be here taken as a metaphor for the geminal ideas disseminated by Stránský's museological thinking. Very early, in the mid-1960s, he conceived the foundations of a discipline that connects the museum work to theory through what he understood as museology.

His metatheory specifically designed for museology was the linking element that was missing for the transformation of museum practice, with the goal to attend to social needs that were in the base of the development of the museum institution. Saying that Stránský has founded the discipline as we know it in the $21^{\text {st }}$ century might not be an exaggeration if we consider what was the main motivation for his ideas: to create a corpus of specific knowledge that could be systematically taught for training museum professionals. His project, first initiated in Brno, would gain followers in virtually every part of the world, first with the International Committee for Museology ICOFOM, created in 1977, and with his International Summer School of Museology - ISSOM (1986-1999).

Born in Kutná Hora, the old Czechoslovakia, in $26^{\text {th }}$ October, 1926, Zbyněk Z. Stránský - as he used to sign his papers - studied history and philosophy at Charles University, in Prague, from 1946 to 1950. During the 1950s, he worked in several Czech museums and in 1962 he was appointed the head of the innovative Department of Museology of the Moravian Museum and the J. E. Purkyně University, in Brno. There, he has established, under the influence of Jan Jelínek (1926-2004), the museum director, the first teaching school of museo- logy devoted to museological theory in the world. Already in the 1960s and 1970s, Stránský was considered the leading person of the Central-European museological school, and, according to some voices, "Copernicus of museology". ${ }^{2}$

First, there were museums. Then, museology. In the middle, there was, and somehow there still is, Stranskian geminal thinking as the missing element for our disciplinary structure. Beyond defending museology as a science, Stránský's ideas dislocated the focus of museum studies from the collections and the very museums, to the processes that constitute them: musealia, museality and musealization would be his key concepts to understand the full process of attributing value to things. This chemist has created a new branch of studies, inaugurating a museological school and provoking the awakening of a theoretical consciousness for museology that is indispensable for any study in this area today.

The museum field and museology: the origins of the Brno School

The history of museology as an academic discipline begins in a museum. It was the year of 1962, when some professionals of the Moravian Museum, in Brno, Czechoslovakia, have presented to the Philosophical Faculty of the J. E. Purkyně University the proposal of creating a Department of Museology, institutionally connected both to the museum and the university. The idea was seen by many "as an attempt to enforce a measure which had no prospect of success and which sooner

\footnotetext{
2 DOLÁK, Jan. Museologist Zbyněk Zbyslav Stránský - Basic Concepts. In BRULON SOARES, Bruno, Anaildo Bernando BARAÇAL and Luciana Menezes DE CARVALHO. Stránský: a bridge Brno-Brazil/ Stránský: uma ponte Brno-Brasil. Papers from the III Debates Cycle in Museology, Rio de Janeiro, Universidade Federal do Estado do Rio de Janeiro - UNIRIO, International Committee for Museology - ICOFOM, unprinted.
}

or later would prove to be a failure." 3 However, the proposal was approved for the initiation of an experimental project. The main goal, shared by both institutions, was the establishment of a specialized training program for the museum staff in "museology".

In this first stage of specialized training for museum professionals, it was clear that the J. E. Purkyně University would not have the financial means or even the personnel to properly ensure its continuous operation. For this reason, the teaching of museology in the new Department was dependent on professionals from the museum staff and some collaborators from other Czech museums. ${ }^{4}$ The challenge taken on by these museum workers, who had no legitimate place at a university, was to create and defend a theoretical conception of museology, as well as a structured system of thought that could justify the existence of this discipline in the framework of university education. Furthermore, at the same time that museology should prove to be theoretically based, its training should present practical results for museum work. Hence, according to the Faculty dean, in 1974, the graduated professionals in this branch of studies:

are equipped - as has been shown mainly by their diploma theses not only theoretically, but also for the efforts to work out a new and truly progressive form of museum work, fully conscious of the importance and specific role of the museum in society and able, therefore, to perform really fundamental, pioneer work in the urgent qualitative

\footnotetext{
3 See the statement of Milan Kopecký, dean of the J. E. Purkyně University in 1974, in STRÁNSKÝ, Zbyněk Z. Brno: Education in Museology. Museological Papers V, Supplementum 2, 1974.

4 Kopecký, Milan, in STRÁNSKÝ, Zbyněk Z. Brno: Education in Museology. Museological Papers V, Supplementum 2, 1974, p. 8.
} 
transformation of the running of museums. ${ }^{5}$

The craved transformation was in the very museum as a space of work for these professionals, but further - and indistinctly, according to the ICOM president and director of the Moravian Museum, Jan Jelínek - of "making a real profession of museum work." 6 For Jelínek, the profession is not a question of whether a person is or is not employed in a museum, but primarily whether this person has acquired the specific knowledge. In this sense, in the beginning of the 1960s, the question frequently posed by museum workers was: "from where should an employee or specially the beginner acquire such a specialized knowledge?"

In fact, in the context in which several of the so-called contemporary sciences were being configured, a museum professional wouldn' t know the difference exactly between the work he or she is carrying out as a specialist in the environment of a museum for example, in biology, zoology, anthropology or archeology - and the work of his/her colleagues employed as teachers at a university or research institute. ${ }^{7}$ Their practice, in general, was determined by other specialties whose focus was in the museum collections as products of different sciences and the specific knowledge produced from them. Meanwhile, there was not a branch of studies dedicated to the museum processes, its function and organization.

Was the work of museum professionals being limited by the very collections they helped to preserve? Was the museum devoid of a special knowledge produced from

\footnotetext{
5 Idem, p. 8

6 Jelínek, Jan, in STRÁNSKÝ, Zbyněk Z. Brno: Education in Museology. Museological Papers V, Supplementum 2, 1974, p. 10.

7 Idem, p. 10
}

its practice? In reality, research developed on the very museum collections was held by university scholars. What was left, then, for museum professionals as knowledge producers?

A drastic transformation in the profile of these professionals would take place in the Moravian Museum in the 1960s. Stránský, as head of the recently created Department of Museology, would master a way through which his theory, taught as "museology" in this very museum, would revolutionize practice and assure a place for museologists as thinkers and researchers, instead of mere museum technicians.

The years of 1964 and 1965 were marked by public museological seminars organized by the department of the faculty and the Moravian Museum together. They had the double aim of, from one side, testing the solution for some museological problems and, from the other, advertising museology. Between $22^{\text {nd }}$ and $23^{\text {rd }}$ March, 1965, the first museological symposium counted with the wide participation of scholars beyond the general public, when the question on the scientific character of museology was put. ${ }^{8}$ According to Stránský, through these seminars, several participants were motivated to study museology. In the middle of 1965, the Ministry of Culture approved the proposal to create a post-graduate program in museology in Brno, allowing the system of education in the country to train professionals in different levels. ${ }^{9}$

The Brno School was recognized by the strong theoretical scope of

\footnotetext{
8 For Stránský, with the goal to discuss museology as a science and its teaching, this symposium witnessed the growing interest of a wide group of scientists - and not only museum professionals - for museology. STRÁNSKÝ, Zbyněk Z. Brno: Education in Museology. Museological Papers V, Supplementum 2, 1974, p. 18.

9 The post-graduate course in museology began its activities in the semester between 1965 and 1966. Idem, p. 19.
}

museological education and for the dissemination of pioneer ideas on museology. With its innovative organization aligning the practice in the Moravian Museum with the theoretical reflection under the auspices of the Philosophical Faculty of a university, the school marked momentarily the conception of museology as a scientific discipline, justified in its theory and methods, primarily, only in the provocative ideas proposed by Stránský. These ideas, that came from a museum professional, would gain a certain centrality in the academic production in Eastern and Central Europe when several new museology schools were created in the region under the influence of the Czech education project in the following decades.

In $20^{\text {th }}$ June, 1968, the students of the first class of museology received their university diplomas in Brno. ${ }^{10}$ As reported by Stránský, most of them were museum directors or professionals who already had a degree in another disciplinary field. The museology course had the duration of two years, with four sessions composed of one hundred lessons each, including theoretical courses and practical lessons. The themes of the classes were divided between general museology and special museology. In the end of the course, students had to defend a theoretical thesis in museology. With the graduation of the first class, Stránský would comment on the accomplishment:

On this occasion it is necessary to mention that it was for the first time that the expert study of museology was realized within the scope of university studies and where the graduates were awarded the extension of their expert qualification by the field of museology. ${ }^{11}$

\footnotetext{
10 STRÁNSKÝ, Zbyněk Z. The first museology graduates in Brno. ICOM News/Nouvelles de l'ICOM, 1969, June, vol. 22, no. 2, pp. 61-62. 11 Idem, p. 62.
} 
According to the course structure determined by Stránský, "general museology" consisted in "problems relating to the conception of museology" considered as a "scientific branch", and mainly composed of theoretical contends involving documentation, selection and communication; "special museology" followed the structure of "general museology", but referred to concrete problems resulting from the correlation between museology and related branches. The concluding part of the course was concentrated in questions selected from the field of museography, whose emphasis was in the factors resulting from the "institutional character of the museum and techno-organizational factors that condition its functioning." 12

In effect, what has marked the Brno School, in comparison to other schools of museology in the world, was Stránský's claim for the statute of science for museology. The term, that is more widely spread after the 1950s presenting the derivatives museological and museologist, applied, in general, to all that refers to the museum and the exercise of the museum practice. ${ }^{13}$ In France, for instance, this wide notion of museology would compete with the term museal; the same would happen in North American countries where the notion would be close to museum business, ${ }^{14}$ such an imprecision is analogous in the context of Latin-American countries as well.

Museology, a term that acquired different connotations throughout

\section{Idem.}

13 DESVALLÉES, André. Cent quarante termes muséologiques ou petit glossaire de l'exposition. In DE BARY, Marie-Odile and Jean-Michel TOBELEM (eds.). Manuel de muséographie. Petit guide à l'usage des responsables des musées. Biarritz: Séguier,

1998, pp. 205-251.

14 Idem. the $20^{\text {th }}$ century and even before, ${ }^{15}$ thanks to the attempt to obtain academic legitimacy by some Czech museum professionals, it would gain a new dimension, from the 1960s, providing the necessary bases for museum work. In this perspective, museology would be configured as a discipline of the interstices, existing between two professional spheres: the practice, that is not necessarily limited by the empirical universe of the museum; and reflexive theory, that would make museum professionals (or museologists) become, rather than mere technicians, real thinkers.

\section{ICOFOM and the international role of Stranskian theory}

It is true that, in its initial stages, Stranskian theory has generated a confusion in the interpretation of commonly used categories and expressed chaos exposing museology's anti-structure. Thanks to the uses of terms unknown by the majority of thinkers of other regions, the terminology employed in the first papers and in classes was much criticized. ${ }^{16}$ According to Suely Cerávolo, the use of what the author calls a "lexicon of Brno"17 didn' $t$ facilitate the full comprehension of the museological themes for the ones who weren' $t$ familiar with it. Terms such as "musealia", "museality", "museistic", among others, were not seen in the West, and did not present an equivalent

15 On the history of the term until the $20^{\text {th }}$ century, see AQUILINA, Janick Daniel. The Babelian Tale of Museology and Museography: a history in words. Museology: International Scientific Eletronic Journal, 2011, no. 6, pp. 1-20; and DESVALLÉES, André and François MAIRESSE. Dictionnaire encyclopédique de muséologie. Paris: Armand Colin, 2011.

16 Burcaw (1981), in CERÁVOLO, Suely Moraes. Da palavra ao termo - um caminho para compreender a museologia. São Paulo: Universidade de São Paulo, Escola de Comunicação e Artes, 2004. PhD Thesis.

17 CERÁVOLO, Suely Moraes. Da palavra ao termo - um caminho para compreender a museologia. São Paulo: Universidade de São Paulo, Escola de Comunicação e Artes, 2004. PhD Thesis. in the English language. ${ }^{18}$ Accused of fabricating a philosophical theory of the Museum, only taught at the J. E. Purkyně University, in Brno, in fact Stránský and his colleagues were talking about changes in the conception of the museum that were being noticed around the world. They established a grand part of what would become, in the following decades, the museological theory mostly disseminated within ICOFOM.

The idea of a theoretical base for museology, was motivated by Jelínek's strong belief in the fact that museum work needed theoretical studies - a motivation that was later shared by Stránský. In fact, university disciplines in Czechoslovakia required a theoretical base to be a science, defining science more broadly than the Anglos-Saxon definition of only the physical world with tangible studies of cause and effect. ${ }^{19}$ It was only in the mid1980 s, with the worldly recognized ISSOM, organized by the Moravian Museum and with support from UNESCO, that the theory developed strictly in the Brno context would become known internationally and respected by peers of scholars and museum workers.

Since the beginning of the decade, a part of this theory would start to circulate in the world thanks to the efforts of the Czechs Jan Jelínek and Vinoš Sofka (1929-2016), with the realization of the first ICOFOM publications dealing with subjects that were central for the configuration of scientific museology, along with the organization of the committee's first international symposiums. In 1980, one of the first sessions held in Mexico, dur-

\footnotetext{
18 Idem, p. 125.
}

19 Of course, Jelínek was an anthropologist by training and this also brought him to look for understanding of the need for mankind to collect and display. NASH, Suzanne. Interview for the special Project The History of Museology, International Committee for Museology - ICOFOM, 2 December, 2015. 
ing the ICOM General Conference, have been devoted to the theme of "the systematics and the theory of systems in museology." ${ }^{20}$ The first issue of a bilingual international journal was published in the same year, in which authors from different origins discussed the notion of a scientific museology. ${ }^{21}$ The wide dissemination of the first issue, in both sides of a politically divided Europe, resulted in the organization of a second issue in $1981 .^{22}$ Stránský, along with Anna Gregorová and other Eastern European authors published in both issues and became known in different parts of the world.

The committee for museology had embraced the theoretical notions disseminated, at first, from Czechoslovakia, allowing these ideas to influence different museologists and schools of museology around the globe. Until the beginning of the 1990s, ICOFOM had expressed its mission to "establish museology as a scientific discipline." 23 Stránský has continually influenced this committee and participated in several of its meetings, becoming an elected member of its Executive Board in 1986.

Since its initial years, ICOFOM has shared some of ICOM's concerns with a terminology for the museum field. In one of the initiatives,

20 JELÍNEK, Jan. Letter from the Chairman. Museological News. Semi-Annual Bulletin of the International Committee of ICOM for Museology, 1981, may, no. 1.

21 See SOFKA, Vinoš (ed.). MUWOP: Museological Working Papers/DOTRAM: Documents de Travail en Muséologie. Museology - Science or just practical museum work?, 1980, vol. 1.

22 The Editorial Board have received twenty new articles for the second issue of the Museological Working Papers. A third issue was being planned, and it intended to discuss the theme of "the object/subject of museology". However, for the lack of financial resources it could not be organized. SOFKA, Vinoš. A message from Dr. Sofka. Museological News, Semi-Annual Bulletin of the International Committee of ICOM for Museology, 1981, may, no. 1.

23 ICOFOM - International Committee for Museology. Museological News. Semi-Annual Bulletin of the International Committee of ICOM for Museology, 1992, June, no. 15. the committee creates, between the years 1985 and 1986, a working group for the organization of a Treatise on museology joining ICOM's project, dating from 1978, to organize a compendium of museum theory. Stránský was assigned to coordinate this group, proposing research on the already known theoretical works in museology. ${ }^{24}$ Also in the 1980s, and in connection to this first project, Stránský was going to work for the organization of a Dictionarium Museologicum, ${ }^{25}$ supposed to be based on terminological research and published in twenty different languages. Indeed, it was not "the elaboration of a system of museology, but merely a classification of a relatively extensive set of words." ${ }^{26}$ During the most part of that decade, he played a prominent role in these ICOFOM projects and in theoretical research both within this committee and in his own Department.

Later, during the ICOFOM annual symposium of 1993, in Athens, Greece, a permanent research project entitled Terminology of Museology was created, aiming to foster a system of basic terms and concepts for museology. The project evolved to the idea of creating a Thesaurus Museologicus, which would be coordinated by the French museologist André Desvallées. In 1997, the first results of this project were presented to the ICOFOM members in two separate sections: the first, a selection of terms organized by Desvallées, prioritizing the history of fundamental

24 STRÁNSKÝ, Zbyněk Z. Working Group on the Treatise on Museology - aims and orientation. Museological News, Semi-Annual Bulletin of the International Committee of ICOM for Museology, 1985, September, no. 8, pp. 25-28.

25 An initiative of ICOM's International Committee for Documentation - CIDOC and the UNESCO Center of Documentation, since 1976, joined by the International Committee for the Training of Personnel - ICOTOP, and, later, by ICOFOM.

26 STRÁNSKÝ, Zbyněk Z. Working Group on terminology. Museological News, Semi-Annual Bulletin of the International Committee of ICOM for Museology, 1985, September, no. 8, p. 29. terms and concepts for museology; the second, coordinated by Stránský, was presented in the form of an encyclopedical dictionary, which the author denominated "a preliminary version of a Museological Encyclopedia." ${ }^{27}$ The document by Desvallées was widely accepted, while Stránský's version of a possible dictionary was rejected, being considered by most of the members and peers as "incompatible with contemporary epistemology." 28

Afterwards, the research done in this area naturally followed Desvallées' methodology, and Stránský, especially after leaving the direction of the ISSOM, in 1998, decreased his participation at ICOFOM meetings. The desire for the organization of an integrated theory for museology in a great part influenced by Stránský's thinking, however, have stayed in the center of the committee's debates for the following years. ${ }^{29}$

\section{Concepts and theorizations: is there an integrated system for museology?}

In 1980, based on his studies from the precedent decades, Stránský defined museology as "a scientific autonomous discipline whose subject of knowledge is a specific approach of man to reality", establishing that

27 Stránský (1998) cited after SCHEINER, Tereza C. Termos e conceitos da museologia: con-

tribuições para o desenvolvimento da Museologia como campo disciplinar. Mast Colloquia, 2008,

vol. 10, p. 213. Documentação em Museus, Museu de Astronomia e Ciências Afins - Mast, Rio de Janeiro.

28 SCHEINER, Tereza C. Termos e conceitos da museologia: contribuições para o desenvolvimento da Museologia como campo disciplinar. Mast Colloquia, 2008, vol. 10, p. 213. Documentação em Museus, Museu de Astronomia e Ciências Afins Mast, Rio de Janeiro.

29 The Dictionnaire Encyclopédique de Muséologie, directed by André Desvallées and François Mairesse, and published in 2011, is a testimony to that fact, as a product of all previous debates and showing a great influence from Stránský's ideas and of his terminology. See, for example, the chapter "Objet [de musée] ou muséalie," in DESVALLÉES, André and François MAIRESSE. Dictionnaire encyclopédique de muséologie. Paris: Armand Colin, 2011, pp. 385-419. 
"the nature of museology is that of a social science" contributing to the "understanding of human society." 30 It was not the first time that museology was being referred to as science, however, in most of the previous definitions, it was constantly identified as "the science which aim is the study of the mission and organization of museums." ${ }^{31}$ What had changed, then, in the Stranskian conception of the term?

What was distinct in this thinker's approach from all the others before him was the fact that beyond merely stating that museology is a science, he tried to prove it. In his structural theory, Stránský was committed to the investigation of essential points considered by him as indispensable for the constitution of a scientific discipline:

(1) first, a science must have defined a specific subject of study; (2) then, a science must use its own set of methods; (3) a science must have a specific terminology, a language; (4) and, at last, it must be based on a theoretical system.32 The search for scientific legitimation, thus, should be followed by the concomitant construction of a theoretical system of museology accordingly to the framework of contemporary sciences. This is due to the fact that,

So far it has not been possible to substantiate the delimitation of museology on an appropriate level as an individual branch of science, mainly because the basic questions of the subject, the methods and the system of museology were not decided and consequently, nei-

30 STRÁNSKÝ, Zbyněk Z. Museology as a Science (a Thesis). Museologia, 1980, vol. XI, no. 15, p. 39.

31 RIVIÈRE, Georges-Henri. Stage régional d'études de l'Unesco sur le rôle éducatif des musées (Rio de Janeiro, 7-30 septembre 1958). Paris: UNESCO, 1960, p. 12.

32 STRÁNSKÝ, Zbyněk Z. Museology as a Science (a Thesis). Museologia, 1980, vol. XI, no. 15, p. 33-39. ther was its place in the system of sciences. $^{33}$

Even so, Stránský has appointed that there were objective reasons for the "birth of museology as a science," ${ }^{34}$ however, its internal prerequisite, i.e., the logical structure, was inexistent. His question on the character of museology, then, made him think on the theoretical base of the very theory. ${ }^{35}$ In other words, Stránský has built a metatheoretical problematic as the starting point for structuring the scientific discipline, introducing the notion of a metamuseology. ${ }^{36}$ The term designates "the theory whose subject is museology in itself", in a certain way being strictly bound to museology, but also related to philosophy, to history and to the theory of science and culture.

In his metamuseological approach, the first problem raised concerned museology's subject of study. Stránský proposed some disconcerting questions for the field under development. With his initial declaration, in which he denies the museum as the scientific subject, ${ }^{37}$ the author opens the way towards a long process of self-reflection that marked museology in its bases in Eastern Europe.

By stating that the "subject of museology is not and cannot be the

33 STRÁNSKÝ, Zbyněk Z. Brno: Education in Museology. Museological Papers V, Supplementum 2. 1974, p. 25.

34 Idem, p. 26.

35 STRÁNSKÝ, Zbyněk Z. Předmět muzeologie. In STRÁNSKÝ, Zbyněk Z. (ed.). Sborník materiálu prvého muzeologického symposia. Brno: Moravian Museum, 1965, p. 31

36 STRÁNSKÝ, Zbyněk Z. Introduction à l'étude de la muséologie. Destinée aux étudiants de l'École Internationale d'Été de Muséologie - EIEM. Brno: Université Masaryk, 1995.

37 STRÁNSKÝ, Zbyněk Z. Předmět muzeologie. In STRÁNSKÝ, Zbyněk Z. (ed.). Sbornik materiálu prvého muzeologického symposia. Brno: Moravian Museum, 1965, pp. 30-33. museum," 38 Stránský intended to separate the "instrument" - or the means, i.e., the museum - and the "end" to which it serves. He alleges, in effect, what could have been considered obvious in the context of post-war museums, which is the fact that the museum, as an institution that serves to a certain end, could not be the study subject of a science. Nevertheless, and in a tautological approach, according to some of his critics, ${ }^{39}$ he would propose that museology's subject of study should be searched in the very museum work, in the "systematic and critical" task of producing the museum object or musealia, in Stranskian terminology.

This thinker was, then, responsible for the dislocation of museology's subject from the museum, as a historic institution, to museality - understood as a "specific documentary value." ${ }^{" 40}$ This last concept, central to his theory, would lead Stránský to conceive the cognitive intention of museology as the scientific interpretation of an "attitude of man to reality". In his opinion, this seizing of the museum character of things, which he called "museality", must be "in the center of the gnoseological intention of museology"41 as this discipline's scientific task, delimiting its position within the system of sciences.

The rupture with the vague idea of a museology strictly devoted to the study of museums, as much as the proposition of the museality notion, allowed Stránský to associate museological theory to museum practice.

38 STRÁNSKÝ, Zbyněk Z. Předmět muzeologie. In STRÁNSKÝ, Zbyněk Z. (ed.). Sborník materiálu prvého muzeologického symposia. Brno: Moravian Museum, 1965, p. 33.

39 See DESVALLÉES, André and François MAIRESSE. Dictionnaire encyclopédique de muséologie. Paris: Armand Colin, 2011

40 STRÁNSKÝ, Zbyněk Z. Brno: Education in Museology. Museological Papers V, Supplementum 2, 1974, p. 28

41 STRÁNSKÝ, Zbyněk Z. Museology and Museums. ICOFOM Study Series - ISS, 1987, no. 12, p. 289. 
In this perspective, he would not disregard the museum as a subject of interest but he would understand it as only one of the possibilities of materializing this specific human approach to reality. What he intended, therefore, was to make museum work directly dependent on museological efforts. ${ }^{42}$ In his perspective, the museum practice must not only be understood as indistinct from museological theory, but also it has in the second its main source for innovation and improvement:

Were we to hide our heads in the sand and stick to the traditional methods and procedures, and remain satisfied with the current practice, museum work would get into increasing contradiction with the general progress of society; museums would be pushed onto the periphery of social interest and in the end they would lose not only their social function but also their raison d'être. ${ }^{43}$

His metamuseological reflection was the mark zero for the development of a critical thinking on museology and its scientific subject in Central and Eastern Europe. The theory of museology, born from this reflection, was systematically taught to professionals and scholars from all around the world in the renowned ISSOM, at Masaryk University. ${ }^{44}$ It was, also, widely debated, with the support of Jelínek and Sofka, from the end of the 1970s and the beginning of the 1980s, within ICOFOM. Nevertheless, the theory as envisaged by Stránský and some of his followers would never exist as an integrated system.

42 Idem, p. 290

43 STRÁNSKÝ, Zbyněk Z. Brno: Education in Museology. Museological Papers V, Supplementum 2, 1974, p. 26.

44 The Masaryk University was founded in Brno in 1919 and it is currently the second largest university in the Czech Republic. In 1960, the university was renamed Jan Evangelista Purkyně University, taking the name of the Czech biologist. In 1990, following the Velvet Revolution it regained its original name.
On the contrary, at first, his theoretical conceptions, drawn from the possibilities of international dialogues, would promote a constant and critical look to museology, capable of the permanent questioning of its own structure. Such a critical museological consciousness, we may say that we have inherit it in our days.

From metamuseology to just museology: Stránský's conceptual triad

By defending that "the museum phenomenon is truly the expression of a specific relation of man to reality," ${ }^{45}$ and that such a relation, to be studied and properly understood, demands specific knowledge that is not provided by other existent sciences, Stránský sustained the statute of science for museology, developing his metatheoretical conceptual base. His theory of theory had the purpose to, more than raise ontological questions for museology, or finding their answers, structuring a theoretical corpus of concepts and methods serving as a basis for the conscious practice.

The concepts formulated and defended by this author that have had a central role in his works, in fact, were not dealing with the museum in its organization and functions. Differently, they were presented to his students and readers as museological concepts, that would supposedly justify the existence of the scientific discipline he was defending:

In order to accomplish, at the same time, its scientific mission, but also its humanitarian mission, museology cannot limit itself to the problems of museum management, of showcases installation or the conservation of one object or another.

45 STRÁNSKÝ, Zbyněk Z. Introduction à l'étude de la muséologie. Destinée aux étudiants de l'École Internationale d'Été de Muséologie - EIEM. Brno: Université Masaryk, 1995.
It is true that all that is part of museology, but those are only means to achieve certain aims. Museology must explain why we do all that, why a certain object is musealized, why we contradict natural changes and disappearances and why [...] we preserve certain elements of reality. ${ }^{46}$

First approaching the very objects to justify the existence of this science of values - or the science of the construction of values - attributed to things, Stránský used the neologism musealia ("muzeálie", in Czech), built from Latin, to refer, museologically, to the museum object. Namely, those objects whose value could be perceived beyond the specific quality they may present to the other fields of knowledge that study them in museums, but considering all their documentary possibilities from the point of view of museology. The term was introduced in the middle of the 1960s and it was refined in Stránský's works since then, as well as the other concepts that he proposed.

The musealia, or museum objects, have museological relevance because they can be perceived, as put by the anthropologist Jean Bazin, as "available objects", ${ }^{47}$ being available to different purposes and interpretations, or, as "becom-

\footnotetext{
46 "Pour remplir à la fois sa mission scientifique, mais aussi sa mission humanitaire, la muséologie ne peut se limiter aux problèmes de la gestion du musée, de l'installation d'une vitrine ou de la conservation de tel ou tel objet. Il est vrai que tout ceci fait partie de la muséologie, mais ce ne sont que des moyens servant à atteindre certains objectifs. La muséologie doit expliquer pourquoi nous faisons tout cela, pourquoi tel objet est muséalisé, pourquoi nous contrarions les changements et les disparitions naturels et pourquoi [...] nous préservons certains éléments de la réalité. ", in the original. Translation by the author. See STRÁNSKÝ, Zbyněk Z. Introduction à l'étude de la muséologie. Destinée aux étudiants de l'École Internationale d'Été de Muséologie - EIEM. Brno: Université Masaryk, 1995, p. 6.

47 BAZIN, Jean. Des clous dans la Joconde. In BAZIN, Jean. Des clous dans la Joconde. L'anthropologie autrement. Toulouse: Anacharsis, 2008, p. 523.
} 
ing-objects" 48 breaking with their symbolic or documentary unity. In effect, the museum object is not the same as the object in a museum, being its attributed value less related to an institutional status and more determined by the social frameworks that give them a museological status.

This would be the specific museological perspective on the objects on which Stránský has projected the notion of "bearers of museality", introducing, thus, the second key-concept of his theory. As he put it:

The task of museology is therefore - at least in our opinion - to perceive and identify such documents which in every respect best represent certain social values and therefore warrant selection, collection and presentation in the interest of society's development.

To give a name to this specific documentary value, conditioned by the quality of the bearer, we are trying to introduce the term Museality.

Simultaneously, to name the bearer document itself we prefer the expression Musealia. ${ }^{49}$

And he continues:

\section{Summing up:}

The object of the knowledge-acquiring intention of museology is museality, conceived in the context of the entire historic, present and future social function..$^{50}$

Hence, the concept of museality ("muzealita"), understood as the "quality" or "value" of musealia, appeared in Stránský’s works in

48 BRULON, Bruno. Os objetos de museu, entre a classificação e o devir. Informação \& Sociedade Estudos, jan./abr. 2015, vol. 25, no. 1, pp. 25-37, passim.

49 STRÁNSKÝ, Zbyněk Z. Brno: Education in Museology. Museological Papers V, Supplementum 2,

1974, p. 28.

50 Idem, p. 28
$1970,{ }^{51}$ being proposed as museology's true subject of study. The first attempts to define the term, however, have presented logical problems. If museology studies the value existent in things, or their museum quality, this discipline would be closer to a prescriptive branch of knowledge than to a social science. Nevertheless, according to Stránský himself, the role of the museologist shouldn' $t$ be one of pointing out the value in things, but the one of understanding how and why certain objects acquire value.

Due to this imprecision, the idea of an object bearer of museality would be put under questioning and Stranskian theory would suffer with severe criticism, notably throughout the 1980s. The museologist from the ancient German Democratic Republic, Klaus Schreiner, for instance, hasn' $t$ conceived museality as the property of an object as such but as something that is attributed to the object only in the context of a particular, specialized discipline. According to Schreiner, there cannot be a value "in itself" and the concept of museality in the Stranskian sense is the product of a "bourgeois-imperialist axiology". He considers that the philosophical value propagated is "timeless, classness and generally not human" and that, as such, it "absolutizes the bourgeois class interests." 52 As noted by Peter van Mensch, Stránský would modify the concept of museality over the years, changing its sense from a value category to the "specific value orientation" itself. ${ }^{53}$

\footnotetext{
51 STRÁNSKÝ, Zbyněk Z. Múzejnictvo v reláci teórie a praxe. Múzeum, 1970, roč. XV, no. 3, pp. 173-183.

52 SCHREINER, Klaus. Forschungsgegenstand der Museologie und Disziplingenese. Neue Museumskunde, 1987, vol. 23, no. 1, pp. 4-8, passim.

53 MENSCH, Peter van. Towards a Methodology of Museology. PhD Thesis [online]. Zágreb: University of Zágreb, 1992 [cit. 2007-07-27]. Available from www: <http://www.muuseum.ee/en/erialane_ areng/museoloogiaalane_ki /p_van_mensch_towar/mensch04>
}

The conceptual problem posed by these authors possibly led the Czech thinker to ask what distinguishes a musealia from other objects in collections. The question of value, or of its social attribution, would finally triggers in Stránský's thinking an interest for the process of musealization, closing his conceptual triad for museology. The notion of "musealization" ("muzealizace”) was explored by Stránský only late in his works. In the journals of museology published by the Moravian Museum and the J. E. Purkyně University from 1969 to 1986, the term appears for the first time in 1972, and then it would reappear only in $1979 .{ }^{54}$

In effect, the term was not created by Stránský himself, it was appropriated by him. According to Václav Rutar, the term has appeared in museological textbooks in the end of the 1970s and the beginning of the 1980s, being appropriated at the same time by authors from other fields of knowledge who have mentioned it in works from the same period, such as Jean François Lyotard and Jean Baudrillard, as well as in the works by the philosopher Hermann Lübbe, quoted by Stránský as the main source of this notion. ${ }^{55}$

Musealization has been defined by Stránský as "the acquisition of the museum quality", or, even, an expression of the universal human tendency to preserve, against all natural change and degradation, the elements of objective reality which represent the cultural values

\footnotetext{
54 RUTAR, Václav, Geneze pojmů muzeálie, muzealita a muzealizace na stránkách Muzeologických sešitů v letech 1969-1986. Museologica Brunensia, 2012, vol. 1, no. 1, p. 11.

55 Stránský (2000, p. 31) cited after RUTAR, Václav. Geneze pojmů muzeálie, muzealita a muzealizace na stránkách Muzeologických sešitů v letech 1969-1986. Museologica Brunensia, 2012, vol. 1,
} no. 1 , pp. 6-13. 
that man, as a cultural being, needs to preserve for its own purpose. ${ }^{56}$

With his appropriation of such a concept, Stránský re-considers "the subject of museology", noting that it "must be, thus, centered in what motivates musealization, in what conditions the museality and non-museality of things. ${ }^{157}$ But as he recognizes: "it is only by museology's specific methods that it is possible to discover what makes an ordinary object become a museum object." 58 This process, conceived by him as a universal one, of attributing value to things, would demand that museology reconfigured its basic aim from the task of inventing values to the investigation of values themselves. These must be identified and studied by the instructed look of the museologist, according to an axiological methodology that would take the place of an ontological methodology established by museums.

This way, museology's subject of study is once again dislocated, from museality, as a product or "quality", to musealization, as the process that conducts to the specific appropriation - creating culture - of natural reality and human reality at the same time. ${ }^{59}$ What distinguishes musealization from other forms of conservation, according to Stránský, is the decisive moment of transition from material reality as it is presented to its elevation towards the level of the cultural, museological reality.

\footnotetext{
56 "une expression de la tendance humaine universelle à préserver, contre le changement et la dégradation naturels, les éléments de la réalité objective qui représentent des valeurs culturelles que l'homme, en tant qu'être culturel, a besoin de conserver dans son propre intérêt.", in the original. Translation by the author. See STRÁNSKÝ, Zbyněk Z. Introduction à l'étude de la muséologie. Destinée aux étudiants de l'École Internationale d'Été de Muséologie - EIEM. Brno: Université Masaryk, 1995, pp. 28-29.

57 Idem, p. 19.

58 Idem, p. 20.

59 Idem, p. 29
}

This musealized reality is commonly mistaken for the concept of cultural heritage, though, to Stránský, this expression is too vague, and it designates a passive approach. Musealization, on the contrary, depends on an active approach, that involves three ramifications foreseen in his theory for museology: selection, thesaurization and communication.

As selection, he understood the basic theory that allows to identify the "museality potential" in objects, which can be provided by different scientific disciplines. Selection in itself, i.e., the removal of a "bearer" from an original situation, would depend on the recognition of its "museum value". ${ }^{60}$ Thesaurization was understood as the process of inserting an object into the documentary system of the new reality of a collection or museum. Ultimately, museological communication is the process throughout which a collection acquires meaning becoming accessible and disseminating its scientific, cultural or social value. For Stránský, communication is the museological approach to reality and it creates, at the same time, a mutual bound with the original reality that is established "in a qualitatively elevated level." ${ }^{\prime 1}$ Therefore, the specificity of museological communication conditions the specificity of museological documentation.

In other words, the object that is thought by him as a priori the "bearer of museality", is selected accordingly to its "potentiality" based on the existent values, and it may acquire new values when it is communicated in a museological speech. What could, at first, seem contradictory in Stranskian theory, reflects the fact that his initial notion of museality was at-

60 STRÁNSKÝ, Zbyněk Z. Brno: Education in Museology. Museological Papers V, Supplementum 2, 1974, p. 30.

61 Idem, p. 31. tached to a net of values built by societies and, at the same time, fed by musealization. Thanks to the perception of museology as a science that studies, not the values in themselves, but the social construction of values, Stránský is led to assign relevance to the concept of musealization.

Derivative form these initial remarks on museology's central concepts, other theoretical approaches to the discipline would be developed. In Stránskýs definition for theoretical museology we can envisage the foundation for what Peter van Mensch defined as just museology. This Dutch museologist proposes a structure for this "scientific discipline" according to five axes: general museology, theoretical museology (which would be equivalent to metamuseology), special museology, historic museology and applied museology. ${ }^{62}$ To these five central areas, Stránský would include social museology, dedicated to the study of musealization in contemporary societies. Furthermore, van Mensch takes Stranskian museology to another level, seeking its professionalization. In his works, the author proposes the PRC model, which refers to the museums basic functions of Preservation, Research and Communication, directly inspired in Stránský's model for musealization, divided, as appointed above, in selection, thesaurization and communication.

Stránskýs museology, therefore, initially conceived of metatheoretical questions, would find some viable ways to the formulation of some hypotheses and other provocations. Finally, museology would

62 This five-fold structure is (since 1982) used by the Reinwardt Academie, in Amsterdam, to provide a framework for the curriculum of museology and to provide a basic classification principle for the library of this institute. MENSCH, Peter van. Towards a Methodology of Museology. PhD Thesis [online]. Zágreb: University of Zágreb, 1992 [cit. 2007-07-27]. Available from www: <http://www. muuseum.ee/en/erialane_areng/museoloogiaalane_ki /p_van_mensch_towar/mensch04>. 
find its subject of study in this inescapable process of reflexive retention, throughout which some things are kept so that they can transmit a certain knowledge through museological communication. The "specific approach of man to reality", mentioned by Stránský, refers, then, to a will of musealization that leads to the social experience of museality.

\section{Stránský and Reflexive Museology}

According to Joanna Overing, exploring a recent crisis of faith in philosophy over the empiricist's paradigm of Rationality, within science the idea of a "single world" is being challenged. ${ }^{63}$ Turning the look to themselves and their own actions, social scientists reveal that the world, from the perspective of our knowledge of it, is how we view it through the paradigms we create. These scientists, differently from philosophers who are usually not asking social questions, are asking about "moral universes" - in Overing's terms - their basic duty being to understand the intentions and objectives of actors within particular social worlds. ${ }^{64}$ Contrary to the modern Western science and the empiricist's proposition that truth is amoral and facts are autonomous from value, facts and truths can be analyzed as being tied to different sets of social, moral and political values.

Thus, all truths have their moral aspect and to hope to find universal and independent criteria of truth has proven to be an unreachable goal that suits only to philosophers who are still defending their con-

63 Overing points out that for instance both Kuhn (1964) and Feyerabend (1975, 1978) forcefully argued against the belief of Western science in a unified objective world unaffected by the epistemic activities of the scientists themselves. OVERING, Joanna. Preface \& Introduction. In OVERING, Joanna (ed.). Reason and Morality. London: Tavistock (A.S.A. Monographs 24), 1985, p. 2. 64 Idem, p. 4. trol over the construction of reality. This has been the case for museum professionals and their crave to control reality by selecting what should be preserved from it.

The task of social sciences, in a different sense, is to understand the knowledge actors have of their own moral universes, considering their standards of validation with respect to it. ${ }^{65}$ The cognitive powers of the Western thought in controlling and knowing the material world are in the base of museums, but they cannot be the foundation of contemporary museology. What is being gradually perceived with the possibility of a science of the science is the fact that Rationality works as a limiting tool for the scientist viewpoint over the Others and specially over him/herself. The Western fetishism for epistemological objects such as reason, truth and knowledge - or, even, the museum is little by little demolishing the ways we relate to moralities and epistemologies different from ours.

Throughout most part of the $20^{\text {th }}$ century, in the first years of the development of museology in the world, the thinkers of the "museum" were not separated from their supposed subject of study. Museum professionals were the ones conceiving "museology". The separation between scientists and their subject of study - that is usually constructed by specific methods hadn't been fully accomplished in museology and maybe still isn' $t$ in our days. Perhaps the reason we are still unable to define the subject of museology is that we are so close to museums we remain their faithful hostages.

What differentiates, though, museology from museum theory or museum studies, even today, is the desire of the first to be acknowledged as

65 Idem, p. 5 a science in the contexts in which this term is being used. In order for that to happen, a distance must be created between scientists and their subject of study. The theory of museology produced in the past forty years is neither a product of museum practice nor the mere expression of couple of philosophical ideas disseminated from Eastern Europe. In fact, the theory is the result of a reflection developed by these thinkers confronted with certain museum practices in the different contexts they acted.

Methodologically speaking, the agents that make museums and their agencies must be studied by the scientists and researchers of museology today if we intend to understand musealization. Nevertheless, when the same people play both roles - the scientist that is also the museum professional - the scientific distance will depend on an exercise of reflexivity on his/ hers own museal practice. Here the museal will be clearly separated from the museological with the artifice of performance.

The first works on museology, by icofomian theorists, were just theory and not science because they consisted in mere reflections lacking the reflexivity that is in part the acknowledgement of performance in the constructed truths and values. The study of the museum performance today allows any scientist to see him/herself as an actor in the stage of the museum representations. Such a reflexivity in the making of science may reveal to be a fundamental process that includes self-knowledge and the revision of paradigms.

Reflexive museology can be perceived, thus, as the permanent consciousness of museology. There is no denying that its first steps were in Stránský's metamuseology. But some of the main social questions weren' $t$ being posed when this 
central thinker in the foundation of our discipline was working solemnly with the Western conception of man-reality relations. His philosophical assertion reifies the separation of man from reality and presupposes the existence of a (material) reality that is divorced from society.

Furthermore, if we perceive the museum as the instrument that performs the relation of man to reality, then musealization is the action towards which we should direct our interest as social scientists. In this sense, Stránský was being reflexive when affirming that the subject of a "social museology" would be, in his perspective, "the musealization of reality in the context of current society." ${ }^{\prime 66}$ Even so, the human, the actor of musealization, is not seen as reality, but as someone who will act on it.

In the case of musealization, it is not "man" or things that will prevail, but the multiple associations ${ }^{67}$ between them. Because associations prevail, we can conceive, for instance, calculation without a calculator, acceleration without a car, or even education without a school. ${ }^{68}$ Musealization, then, exists beyond the museum. As well as the hammer does not impose the hitting of the nail, museums do not impose musealization. In fact, museums are the mediators and not the main actors of musealization; they participate in the action, but they cannot configure, in any conceivable way, the sole subject of museology.

66 STRÁNSKÝ, Zbyněk Z. Introduction à l'étude de la muséologie. Destinée aux étudiants de l'École Internationale d'Été de Muséologie - EIEM. Brno: Université Masaryk, 1995, p. 28.

67 Here we use the term according to the sense given by Bruno Latour. See LATOUR, Bruno. Reassembling the Social: An Introduction to Actor-Network-Theory. New York: Oxford University Press, 2005.

68 Idem, p. 71
As a theoretical concept, musealization is the very practical action that has founded museums. The artificial separation between theory and practice, or museology and museography, for so long has represented a difficult breach to be supplanted in the heart of this discipline. ${ }^{69}$ Even today, in most contexts of the world, museum professionals do not identify as museologists, and the idea of a social science that studies the process of musealization in social terms is unclear. The idea to find a structure encompassing both practical museum work and theoretical museology was Stránský's biggest challenge. But his metatheory hasn' $t$ proved to be convincing enough for a real scientific revolution.

What is certain, today, is that we have moved from the prescriptive field of museum practice, to a reflexive field devoted to the critical study of the existent practice and we are finally able to produce theoretical questions in order to provoke change.

In this sense, how should a scientific discipline be formulating relevant questions for its own development? For instance, how conscious are we of our own role in building museality? How do we recognize ourselves, as scientists, in the process of musealization? Or in making museological communication with "true" objects? These are questions Stránský did not had the opportunity to ask, but we do, probably thanks to him.

\section{Some conclusions}

As every metaphor has its limitations, in "geminal", the prefix gem, in Latin, denotes "twin", which is

\footnotetext{
69 See, for example, RIVIÈRE, Georges-Henri. Stage régional d'études de l'Unesco sur le rôle éducatif des musées (Rio de Janeiro, 7-30 septembre 1958). Paris: UNESCO, 1960; and GLUZIŃSKI Wojciech. Basic paper. Methodology of museology and professional training. ICOFOM Study Series ISS, 1983, no. 1, pp. 24-35.
}

not at all the case between museum work and the theory of museology. A symbiosis would be the better metaphor to explain how the two fields interact today, constituting the sole field of museology, embracing theory and practice.

As Stránský has put it, if we intend to get into a creative relation with museum practice, then we have to accept that "all that arises the need for museums and all that finds its materialization in museums should be the subject of museology."70 There is nothing wrong with admitting that disciplinary museology comes from museums and it is still, in a certain level, attached to them. However, mostly thanks to Stranskian geminal ideas, museology is no longer limited to the museum. Even though a great part of its contemporary thinkers do not consider museology a science yet - although recognizing its potential to be perceived as a social or human science in the near future -, most of them consider the "new" subjects of study that have somehow given life to the discipline as it is being taught in universities.

What has changed, then? If in the beginning of the 1980s the first attempts to summarize a theory for museology was based on the authors singular museum experiences, later, some museologists ${ }^{71}$ have appointed a more realistic solution for the scientific discipline. Research was the answer. The truth of the matter is that no philosophical system would generate a science or its subject without a considerable amount of empirical and theoreti-

\footnotetext{
70 STRÁNSKÝ, Zbyněk Z. Museology and Museums. ICOFOM Study Series - ISS, 1987, no. 12, p. 289.

71 MENSCH, Peter van. Towards a Methodology of Museology. PhD Thesis [online]. Zágreb: University of Zágreb, 1992 [cit. 2007-07-27]. Available from www: <http://www.muuseum.ee/en/erialane_ areng/museoloogiaalane_ki /p_van_mensch_towar/ mensch04>; TEATHER, Lynne. Some brief notes on the methodological problems of museological research. ICOFOM Study Series - ISS. Methodology of museology and professional training, 1983, no. 5, pp. 1-9.
} 
cal research on the very discipline and its constitutive processes.

What substantially prevents the existence of a science entitled $\mathrm{mu}$ seology today is still the fact that its theoretical production and its methods are marked by the Cartesian idea of the museum designed, as a metaphor and literally, in the rationalist system of knowledge fabricated in Western Modernity. In this "museum" that organized objects and ideas - or ideas as objects - things were created to be put in the shelves of knowledge in order to be observed, categorized, counted, weighted and measured by the encyclopedic scientist. Man was very much separated from things, and things were fully dominated as passive objects in the gnosiological relation.

Museology, born in museums of this kind and conceived by the professionals working in these institutions, has inherited their dogmas. For sciences that strongly desire to control its own part of reality - as in the traditional human sciences in general - the notion according to which human beings invent their reality is debated with great difficulty. The apparent solution to supplant the problem is, in most of the cases, the centrality of empirical work aiming to deconstruct the established truths and implement the discussion of the methods in this process.

The discussion of a specific method for museology will raise two fundamental questions: first "how museology molds the practice?", and second, "how the practice molds museology?". Certainly, museology cannot be the science that studies the limited and undefined universe of the museum. The very concept of the "museum" is used to explain heterogeneous experiences, to which theorists refer as a "pheno- menon"72 related to the terms "museology", "museography", "theory of museum", "museistic", ${ }^{73}$ and so on... It is fragrantly an artifice of method, created as such to justify the existence of a profession entitled museology.

We can witness today new approaches to museums, from a museological perspective, that only exist because some thinkers are no longer attached to their very subject of study. In some of these studies, the museum is a mere instrument for musealization, understood as a social process and critically analyzed considering its cultural and political implications beyond the institution. Their aim is to deconstruct the institutional forms of retaining meaning through the appropriation of heritage. Some of these studies, based on serious research, are deeply committed to the investigation of museology's fundamental problems and they help to answer many of the questions posed in the present paper. The only reason they do so, is by working at once with practical issues and theoretical reflections.

If the study of museology is museology, thus, by considering the reflexive investigation of the mediations that formalize the wide process of musealization, we have a concrete empirical field for this discipline that is both theoretical and practical. It is clear, therefore, that an effective science may conceive musealization as an agency and all the persons and objects involved in it as agents. To find the tracing of these associations would be the work of the conscious museologist, who is not the museum professional

72 SCHEINER, Tereza C. Musée et Muséologie Définitions en cours. In MAIRESSE, François and André DESVALLEES (eds.). Vers un redéfinition du musée. Paris: L’Harmattan, 2007, pp. 147-165.

73 STRÁNSKÝ, Zbyněk Z. [Without title]. In SOFKA, Vinoš (ed.). MUWOP: Museological Working Papers/DOTRAM: Documents de Travail en Muséologie. Museology - Science or just practical museum work?, 1980, vol. 1, p. 43. but the scientist who is also implicated in his/hers subject of study. As the epistemologist who thinks about "the meaning of meaning", or the psychologist who thinks about how people think, the museologist can also be seen as the one who thinks about the museological "thinking" - and in this sense, Stránský wasn' $t$ wrong by suggesting the existence of "metatheoretical problems" for his science.

\section{REFERENCES:}

AQUILINA, Janick Daniel. The Babelian Tale of Museology and Museography: a history in words. Museology: International Scientific Eletronic Journal, 2011, no. 6, pp. 1-20.

BAZIN, Jean. Des clous dans la Joconde. In BAZIN, Jean. Des clous dans la Joconde. L'anthropologie autrement. Toulouse: Anacharsis, 2008, pp. 521-545.

BRULON, Bruno. Os objetos de museu, entre a classificação e o devir. Informação \& Sociedade: Estudos, jan./abr. 2015, vol. 25 , no. 1 , pp. $25-37$.

CERÁVOLO, Suely Moraes. Da palavra ao termo - um caminho para compreender a museologia. São Paulo: Universidade de São Paulo, Escola de Comunicação e Artes, 2004. PhD Thesis.

DESVALLÉES, André. Cent quarante termes muséologiques ou petit glossaire de l'exposition. In DE BARY, Marie-Odile and Jean-Michel TOBELEM (eds.). Manuel de muséographie. Petit guide à l'usage des responsables des musées. Biarritz: Séguier, 1998, pp. 205-251.

DESVALLÉES, André and François MAIRESSE. Dictionnaire encyclopédique de muséologie. Paris: Armand Colin, 2011. $722 \mathrm{p}$.

DOLÁK, Jan. Museologist Zbyněk Zbyslav Stránský - Basic Concepts. In BRULON SOARES, Bruno, Anaildo Bernando BARAÇAL and Luciana Menezes DE CARVALHO. Stránský: a bridge Brno-Brazil/ Stránský: uma ponte Brno-Brasil. Papers from the III Debates Cycle in Museology, Rio de Janeiro, Universidade Federal do Estado do Rio de Janeiro - UNIRIO, 
International Committee for Museology ICOFOM, unprinted.

GLUZIŃSKI, Wojciech. Basic paper. Methodology of museology and professional training. ICOFOM Study Series - ISS, 1983 , no. 1 , pp. 24-35.

ICOFOM - International Committee for Museology. Museological News. Semi-Annual Bulletin of the International Committee of ICOM for Museology, 1992, June, no. 15.

JELÍNEK, Jan. Letter from the Chairman. Museological News. Semi-Annual Bulletin of the International Committee of ICOM for Museology, 1981, may, no. 1.

LATOUR, Bruno. Reassembling the Social: An Introduction to Actor-Network-Theory. New York: Oxford University Press, 2005. $328 \mathrm{p}$.

MENSCH, Peter van. Towards a Methodology of Museology. PhD Thesis [online]. Zágreb: University of Zágreb, 1992 [cit. 2007-07-27]. Available from www: <http://www.muuseum.ee/en/ erialane_areng/museoloogiaalane_ki /p_van_mensch_towar/mensch04>.

$\mathrm{NASH}$, Suzanne. Interview for the special Project The History of Museology, International Committee for Museology ICOFOM, 2 December, 2015.

OVERING, Joanna. Preface \& Introduction. In OVERING, Joanna (ed.). Reason and Morality. London: Tavistock (A.S.A. Monographs 24), 1985, pp. 1-28.

RIVIÈRE, Georges-Henri. Stage régional d'études de l'Unesco sur le rôle éducatif des musées (Rio de Janeiro, 7-30 septembre 1958). Paris: UNESCO, 1960. 63 p.

RUTAR, Václav. Geneze pojmů muzeálie, muzealita a muzealizace na stránkách Muzeologických sešitů v letech 19691986. Museologica Brunensia, 2012, vol. 1, no. 1, pp. 6-13.

SCHEINER, Tereza C. Musée et Muséologie - Définitions en cours. In MAIRESSE, François and André DESVALLEES (eds.) Vers un redéfinition du musée. Paris: L'Harmattan, 2007, pp. 147-165.

SCHEINER, Tereza C. Termos e conceitos da museologia: contribuições para o desenvolvimento da Museologia como campo disciplinar. Mast Colloquia, 2008, vol. 10, pp. 202-233. Documentação em Museus, Museu de Astronomia e Ciências Afins - Mast, Rio de Janeiro.
SCHREINER, Klaus. Forschungsgegenstand der Museologie und Disziplingenese.

Neue Museumskunde, 1987, vol. 23, no. 1, pp. 4-8.

SOFKA, Vinoš. A message from Dr. Sofka. Museological News, Semi-Annual Bulletin of the International Committee of ICOM for Museology, 1981, may, no. 1.

SOFKA, Vinoš (ed.). MUWOP: Museological Working Papers/DOTRAM: Documents de Travail en Muséologie. MuseologyScience or just practical museum work?, 1980, vol. 1. 67 p.

SOFKA, Vinoš (ed.). MUWOP: Museological Working Papers/DOTRAM: Documents de Travail en Muséologie. Interdisciplinarity in Museology, 1981, vol. 2. 98 p.

STRÁNSKÝ, Zbyněk Z. Brno: Education in Museology. Museological Papers V, Supplementum 2, 1974, pp. 7-12.

STRÁNSKÝ, Zbyněk Z. Introduction à l'étude de la muséologie. Destinée aux étudiants de l'École Internationale d'Été de Muséologie - EIEM. Brno: Université Masaryk, 1995. $116 \mathrm{p}$.

STRÁNSKÝ, Zbyněk Z. Museology and Museums. ICOFOM Study Series - ISS, 1987, no. 12, pp. 287-292.

STRÁNSKÝ, Zbyněk Z. Museology as a Science (a Thesis). Museologia, 1980, vol. XI, no. 15, pp. 33-39.

STRÁNSKÝ, Zbyněk Z. Múzejnictvo v relácii teórie a praxe. Múzeum, 1970, roč. XV, no. 3, pp. 173-183.

STRÁNSKÝ, Zbyněk Z. Předmět muzeologie. In STRÁNSKÝ, Zbyněk Z. (ed.). Sborník materiálu prvého muzeologického symposia. Brno: Moravian Museum, 1965, pp. 30-33.

STRÁNSKÝ, Zbyněk Z. The first museology graduates in Brno. ICOM News/Nouvelles de l'ICOM, 1969, June, vol. 22, no. 2, pp. 61-62.

STRÁNSKÝ, Zbyněk Z. [Without title]. In SOFKA, Vinoš (ed.). MUWOP: Museological Working Papers/DOTRAM: Documents de Travail en Muséologie. MuseologyScience or just practical museum work?, 1980, vol. 1, pp. 42-44.

STRÁNSKÝ, Zbyněk Z. Working Group on terminology. Museological News, Semi-Annual Bulletin of the International Committee of ICOM for Museology, 1985, September, no. 8, pp. 29-31.
STRÁNSKÝ, Zbyněk Z. Working Group on the Treatise on Museology - aims and orientation. Museological News, Semi-Annual Bulletin of the International Committee of ICOM for Museology, 1985, September, no. 8, pp. 25-28.

TEATHER, Lynne. Some brief notes on the methodological problems of museological research. ICOFOM Study Series - ISS Methodology of museology and professional training, 1983, no. 5, pp. 1-9.

\section{BRUNO BRULON SOARES}

Universidade Federal do Estado do Rio de Janeiro - UNIRIO,

Rio de Janeiro, Brasil

brunobrulon@gmail.compl

Bruno Brulon Soares is a Brazilian museologist and historian, PhD. in Anthropology, and, since 2013, Professor of Museology Theory in the Department of Museological Studies and Processes - DEPM, at the Universidade Federal do Estado do Rio de Janeiro - UNIRIO (Federal University of the State of Rio de Janeiro - UNIRIO), in Brazil. Currently he is the coordinator of the Research Group Experimental Museology and Image - MEI, at UNIRIO, and ICOFOM Vice-president (2016-2019).

Bruno Brulon Soares je brazilský muzeolog a historik, doktor antropologie (PhD.) a od roku 2013 profesor muzeologické teorie na Katedře muzeologických studií a procesů (DEPM) na Federální univerzitě Rio de Janeiro (UNIRIO) v Brazílii. V současnosti pưsobí jako koordinátor výzkumné skupiny pro experimentální muzeologii a image (MEI) v rámci UNIRIO a je viceprezidentem ICOFOM (2016-2019). 